\title{
Biotechnology applied for sustainable development: social responsibility in the Industry 4.0
}

\author{
Oreonnilda de Souza', Antonio Carlos Massabni ${ }^{2}$ \\ *Corresponding author: E-mail address: oreonnilda@gmail.com
}

Abstract: This research was conducted from a review of bibliographic content on Biotechnology, sustainable development, social responsibility and Industry 4.0. The goal endows the understanding of the role of Biotechnology as a science in sustainable development in this historical phase experienced by humanity, the Fourth Industrial Revolution, verifying what would be the social responsibility of Industry 4.0 in this context. Dialectical and historical methods were used to systematize the obtained data. The importance of maintaining the environmental balance through sustainable practices in the daily life of Industry 4.0 has been demonstrated to comply with the constitutional principle of the social function of property. However, in order to achieve sustainable development, the economic and social aspects, besides the environmental, must be considered. The relevance of Biotechnology in this process has been proven as a driving force for sustainable development. It is hoped with this research to mobilize the academic community and the society in the fight against environmental degradation, bringing knowledge about the role of Biotechnology in this process, in the context of Industry 4.0, and demonstrating the need for companies, professionals and governments to adapt to this new and unknown reality in order to face the problems that are already emerging, always taking into consideration the protection of human rights, especially the healthy and balanced environment, safety, life and dignity of the human person.

Keywords: Biotechnology; Sustainable development; Industry 4.0.

\section{Introduction}

Industry 4.0 reflects technological implementations and contemporary business management practices making the production process increasingly efficient, agile, autonomous and customizable through technological innovation. It will be necessary to rethink the old and already obsolete business models, developing research and technologies for industrial production.

However, the same mistake made centuries ago cannot repeat, in which the development of industry has bring environmental degradation and scarcity of natural resources by the unbridled and unthinking use in the production process.

The planet still suffers from the inconsequential acts of the past and, today, the concern is to degrade as little as possible, maintaining the fauna and flora and stabilizing the hole in the ozone layer, responsible for climate change resulting from the environmental imbalance resulting from pollution and destruction of the environment by the mankind.

Under this perspective, this work presents important definitions, including the performance of Biotechnology for environmental protection, applying the results obtained by research and development of innovative technologies capable of promoting sustainable development, ensuring the environment to future generations, as a fundamental right of citizens.

As for the materials, the research will include studies of literary works, scientific articles, legislation and other means of registration and dissemination of data that proved to be necessary for the pursuit of the proposed objectives.

\section{Objectives}

It is intended to demonstrate the importance of maintaining the environmental balance through sustainable practices inserted in the daily life of Industry 4.0, a social responsibility imposed on companies to con- tain degradation in the production process and marketing of goods and services, reaffirming, or better, proving the relevance of Biotechnology in the fight for environmental preservation.

\section{Methodology}

This research was conducted using the following methods: dialectical, to understand social reality, approaching it through argumentative and conflictive dialogue, and historical, analyzing the data from a historical perspective. This is a literature review research, in which several literary works, scientific articles and the legislation applicable to the case were studied to identify the social responsibility of Industry 4.0 and the application of Biotechnology to achieve sustainable development.

\section{Discussion}

\section{Preliminary notions about biotechnology}

The United Nations defines Biotechnology as "any technological application that uses biological systems, living organisms, or derived beings, to manufacture or modify products or processes for specific use". ${ }^{1}$ Maria Antonia Malajovich defines Biotechnology as "an activity based on multidisciplinary knowledge, which uses biological agents to make useful products or solve problems". The author states that this definition encompasses, in a very comprehensive way, various activities such as engineering, chemistry, agronomy, veterinary, microbiology, biology, medicine, law, economics, among others². For Emilio Muñoz, Biotechnology is understood as a set of techniques that allow the application of the properties of living beings to produce goods and services. These techniques are very old, being used for the fermentation of food through microorganisms, originating other products and/or helping in its conservation. ${ }^{3}$

Biotechnology involves numerous scientific areas such as biolo-

1 PhD student of the Graduate Program in Biotechnology, Regenerative Medicine and Medicinal Chemistry of University of Araraquara (Uniara).

2 Professor of the Graduate Program in Biotechnology, Regenerative Medicine and Medicinal Chemistry of University of Araraquara (Uniara). 
gy, chemistry, biochemistry, microbiology, informatics and robotics. Its methods range from simple procedures for modifying living organisms, such as domestication of animals and cultivation of plants, to complex processes, such as biolixiviation, contemporary methods involving genetic manipulation, cell and tissue culture, and nanotechnology. ${ }^{2}$

The Biotechnology sector covers countless business segments, but the activities required for the development process of biotechnological products require high investment for research, testing, performance evaluation, among other crucial stages until the final development of the product, which becomes an obstacle and restricts its use by micro and small companies. In order to obtain competitive advantages, it is essential for these companies to have professionals in the Biotechnology area, formalize partnerships with research and technology centers, in addition to financial resources with the contribution of investors - which is not easy for the small entrepreneur. ${ }^{2}$

In 2007, the Biominas Foundation conducted a survey with Brazilian Biotechnology companies nationwide. The survey identified $181 \mathrm{com}-$ panies in the bioscience sector, 71 forming the Biotechnology sector. In 2009, in a new research, Biominas verified a growth of $40 \%$, in which there were 253 bioscience and 91 biotechnology companies, distributed in seven branches: human and animal health, agriculture, environment, bioenergy, mixed and inputs. The research revealed that many of these companies, with Biotechnology projects, have other main activities, therefore they would not be considered biotech companies. Bioscience companies, on the other hand, are related to the areas of human and animal health, agriculture and the environment, reaching the consensus that every bioscience company is a biotechnology company, however, not every bioscience company is a biotechnology company. ${ }^{4}$

Precisely, Biotechnology multidisciplinary character makes it a science composed of several areas, which were classified in colors according to their fields of application: yellow, blue, white, gray, gold, orange, brown, green, red, black and purple. ${ }^{5}$

Table 2 shows some possibilities for biotechnology-based products and services in various sectors of the economy.

It is important to mention some advantages and also disadvantages of Biotechnology. In order to facilitate understanding, the information was set out in Table 3.

\begin{tabular}{l}
\hline BIOTECHNOLOGY \\
\hline Yellow: intended for food production and nutritional control. \\
\hline Blue: applied in the exploitation of marine biological resources; marine biotechnology. \\
\hline White (also called industrial): dedicated to the production of energy; used in the manufacture of \\
products by means of methods less harmful to the environment. \\
\hline Grey: studies and optimizes recycling processes and other related processes. \\
\hline Golden: used in bioinformatics and computational techniques. \\
\hline Orange (or educational biotechnology): is dedicated to the information, dissemination and \\
dissemination of biotechnology and its applications. \\
\hline Brown: dedicated to obtaining components and making use of desert resources. \\
\hline $\begin{array}{l}\text { Green: it is related to plants and their products; it is applied in agriculture in order to develop more } \\
\text { sustainable conditions. }\end{array}$ \\
\hline Red: applied to both human and animal health; used in medicine to improve treatments and medicines, \\
including genetic manipulation. \\
Black: reflects the set of actions aimed at biodefense to prevent the use of pathogens for bioterrorism; \\
it is also used for warfare purposes (e.g., production of biological weapons). \\
Purple: identifies the legal aspects of biotechnology and its application. \\
\hline
\end{tabular}

Table 1 - Representative colors of the areas of Biotechnology. Source: Dasilva, $2004^{5}$ 


\section{S. Oreonnilda, A.C. Massabni}

\begin{tabular}{|l|l|}
\hline \multicolumn{1}{|c|}{ SECTORS } & \multicolumn{1}{c|}{ PRODUCTS OU SERVICES } \\
\hline Agriculture & $\begin{array}{l}\text { Fertilizer, silage, biopesticides, biofertilizers, seedlings of } \\
\text { disease-free plants, seedlings of trees for reforestation. } \\
\text { Plants with new incorporated characteristics (transgenic): } \\
\text { higher nutritional value, resistance to pests and adverse } \\
\text { cultivation conditions (dryness and salinity). }\end{array}$ \\
\hline Food & $\begin{array}{l}\text { Bakery (bread and biscuits), dairy products (cheeses, } \\
\text { yoghurts and other dairy beverages), beverages (beers, wines } \\
\text { and distilled beverages) and various additives (shoyu, sodium } \\
\text { monoglutamate and sweeteners); single cell protein (PUC) for } \\
\text { rations, foods of transgenic origin with new properties. }\end{array}$ \\
\hline Energy & $\begin{array}{l}\text { Ethanol, biogas and other fuels (from biomass } \\
\text { E). }\end{array}$ \\
\hline Industry & $\begin{array}{l}\text { Butanol, acetone, glycerol, acids and vitamins (sugar-alcohol } \\
\text { production). Numerous enzymes for other industries (textile } \\
\text { and detergents). }\end{array}$ \\
\hline Environment & $\begin{array}{l}\text { Oil recovery, bioremediation (e.g. of water and waste), } \\
\text { bioconversion of waste from agriculture, production of } \\
\text { biofuels and biodegradable plastic. }\end{array}$ \\
\hline Livestock & $\begin{array}{l}\text { Embryos, animals with new characteristics (transgenic), } \\
\text { vaccines and medicines for veterinary use. }\end{array}$ \\
\hline Health (Medicine/Farmacy/Biomedicine) & $\begin{array}{l}\text { Antibiotics and drugs for various diseases, hormones, } \\
\text { vaccines, reagents and diagnostic tests, new treatments, } \\
\text { production of laboratory antibodies for immunodeficient } \\
\text { patients, gene therapy, stem cell research, manipulation of } \\
\text { animals for organ use in transplants, printing of 3D prostheses } \\
\text { and bioprinting of organs in 3D. }\end{array}$ \\
\hline
\end{tabular}

Table 2 - Examples of products and services of biotechnological origin by sectors of the economy. Source: Adapted from Malajovich. ${ }^{2}$

\begin{tabular}{|c|c|}
\hline \multicolumn{2}{|c|}{ BIOTECHNOLOGY } \\
\hline ADVANTAGES & DISADVANTAGES \\
\hline $\begin{array}{l}\text { Improved harvesting (increased production and increased re- } \\
\text { sistance to pests); reduced world hunger. }\end{array}$ & $\begin{array}{l}\text { Dependence on technologies produced by developed } \\
\text { countries; increase in the concentration of income and } \\
\text { wealth. }\end{array}$ \\
\hline Durability of transgenic foods - less waste. & $\begin{array}{l}\text { Increase in the occurrence of diseases caused by transgenic } \\
\text { products. }\end{array}$ \\
\hline $\begin{array}{l}\text { Production of more nutritious or biofortified foods (content of } \\
\text { proteins, fibers, oils, carbohydrates, vitamins and mineral salts) } \\
\text { - OGM/transgenic. }\end{array}$ & $\begin{array}{l}\text { Biodiversity loss; impact on nontarget organisms of the } \\
\text { technology, consequently impacts on biological diversity. }\end{array}$ \\
\hline Decrease in the use of pesticides. & Intensive use of inorganic fertilizers and pesticides. \\
\hline $\begin{array}{l}\text { Use of bioremediation to control and decontaminate environ- } \\
\text { ments. }\end{array}$ & Creation of infertile GM seeds. \\
\hline Reduction of energy in the production process. & $\begin{array}{l}\text { Interference with the balance of nature - effects on the food } \\
\text { chain or food chain (network). }\end{array}$ \\
\hline $\begin{array}{l}\text { Use of products with lower environmental impact - less pollu- } \\
\text { tion and degradation; production of biodegradable products. }\end{array}$ & $\begin{array}{l}\text { Uncertainties regarding the biosafety of the products gen- } \\
\text { erated - potential risks and their probability of occurrence, } \\
\text { in environmental aspects and effects on human and animal } \\
\text { health, especially those of a long-term nature. }\end{array}$ \\
\hline Reduction of contagious diseases. & $\begin{array}{l}\text { Genetic pollution - it is not possible to control the effects } \\
\text { of the spread of genetically modified organisms (GMOs) on } \\
\text { the environment. }\end{array}$ \\
\hline $\begin{array}{l}\text { Development of more precise therapeutic devices and tech- } \\
\text { niques for the prevention, diagnosis and treatment of diseases, } \\
\text { including incurable diseases with ineffective treatments such as } \\
\text { cancer. }\end{array}$ & Ethical issues and permissibility to clone living beings. \\
\hline
\end{tabular}

Table 3 - Advantages and disadvantages of Biotechnology. Source: Adapted from Malajovich. ${ }^{2}$ 
Biotechnology still arouses countless discussions about innovations. Technologies are the result of scientific knowledge, but considered by some people as an unnatural and dangerous activity. When discussing whether biotechnology is progressive or reactionary, good or bad, it is forgotten that what characterizes a technology is its use. ${ }^{2}$

\section{Overview on Industry 4.0}

The name Industry 4.0 began to be used at the Hannover Fair (2011 edition), from a German government's initiative to promote partnerships with technology companies, universities and research centers with a view to changing the paradigm of the production process of industries ${ }^{9}$. This concept encompasses technological innovations in both automation and control, management and information technology in the production and logistics chain of companies.

The 4.0 industry will demand a gradual adoption of several emerging technologies for industrial automation and information technology, with information digitalization and direct communication between systems, machines, products and people. This integration is now known as the Internet of Things (IoT). This process will generate manufacturing environments with high flexibility and self-adjusting to the growing demand for increasingly customized products. ${ }^{9}$

Industry 4.0 is the fruit of the Fourth Industrial Revolution, which is based on a digital revolution defined by more extensive mobile Internet access, by decreasing the size and price of sensors in return for increased capacity and power, and by artificial intelligence and automatic learning that invaded all sciences, promoting frightening advances and unimaginable times such as genetic sequencing, nanotechnology, renewable energies, 3D printers, among others ${ }^{10}$.

According to Klaus Schwab, the Fourth Industrial Revolution will monumentally impact the global economy, because it is expected that every major macrovariable, such as gross domestic product (GDP), consumption and employment, will be affected..$^{10}$

Companies that do not adjust to this new reality will certainly be doomed to failure and will not survive the savage capitalism promoted by globalization.

But how to achieve development and stay in the market fulfilling the social responsibility in the preservation of the environment?

The adoption of good practices in the productive process when the subject is environment is not enough, the need of business models with strategies of adaptation to the scarcity of natural resources is urgent. They need to think in short, medium and long terms, because all business activity provokes environmental impacts, some with greater intensity and others in lesser degree.

Natural resources are finite assets, environmental degradation and overexploitation of these resources cause damage to society as a whole, often irreparable and irreversible. Therefore, the model of production and consumption must be compatible with the material basis of the economy. ${ }^{11}$

According to Sergio Risola, executive director of Centre for Innovation, Entrepreneurship and Technology (Cietec), in the last decade, companies began to see the relationship with the environment as a strategy to adapt to the scarcity of natural resources. This approach has increased consumer and industrial demand for innovation in the socalled green economy. ${ }^{12}$

\section{Corporate social responsibility in the adoption of sustainable} practices: a constitutional determination

As seen, the technological advances that mark Industry 4.0 have brought undeniable benefits, but also, many times in greater intensity, degradation and devastation of the environment, materialized by the pollution of seas, rivers and air, promoting scarcity of natural resources, greenhouse effect, acid rain, evidenced by the climate changes so discussed by nongovernmental organizations and environmental defense entities. ${ }^{13}$

It is a serious mistake to disassociate environment, productive system and consumption, since these aspects are umbilically linked, there is no way to produce without generating environmental impacts, in the same way that there is no way to consume without this impact being accentuated, either by the production of waste, or by the exploitation of human beings in work environments, or by the social inequality promoted by the capitalist and globalized system.

That is why there is no way to deal with sustainability in isolation, that is, the economic, social and environmental dimensions are interconnected.

Companies are responsible for complying with legal requirements for environmental protection and also for observing their social and solidarity function, which are important constitutions.

The property right guaranteed by the Brazilian Federal Constitution (FC) in Article 5, item XXII, is not absolute, i.e., it is limited by item XXIII of the same article: "property shall serve its social function". The FC mentions what is a social function, separating it in the social function of urban property from the social function of rural property. In order for urban property to achieve its social function, it will be necessary to meet the requirements of the city ordinance set forth in its master plan (Art. 182, §2). And the social function of rural property will be fulfilled when the following requirements are met: 1. rational and adequate use; 2. adequate use of available natural resources and preservation of the environment; 3 . observing the regulations on labor relations; 4. exploitation favorable to the well-being of owners and workers (Art. 186) 14 .

The company, as an asset resulting from the unfolding of the property right, an individual right protected by the $\mathrm{FC}$, must also achieve a social function, a harmonizing or even moderating instrument of the exercise of the right to exploit the economic activity legitimized by the principle of free initiative.

As André Ramos Tavares teaches, the Constitution of the Republic attributes a double dimension to property: an individual right and a socioeconomic right, due to their delimitation by the social function, that is "to serve the purposes of the community and not only the individualistic purposes" (p. 567). ${ }^{15}$ In this sense, not only the productive character must be performed by the property, but also the observance of national legislation, including employment contracts, constitutional principles and precepts, under penalty of being held responsible and subject to penalties. The consequences of noncompliance with the social function of the property are: The Government may demand adequacy, granting a deadline for this and/or imposing fines in pecuniary value and even expropriate the property (Articles 182, §4 and 184, CF). ${ }^{14}$

Companies have social and sustainable responsibility, that is, not only with society for the impacts that pollution may generate on human beings, but mainly with respect to environmental degradation, both in the production process so as not to cause exhaustion of natural resources, and in the destination of waste and garbage that their products and services generate.

Therefore, the need for a macroanalysis of sustainability contemplating some of its relevant influencing aspects in an attempt to point out mechanisms capable of controlling and even reducing environmental degradation from the development of biotechnological products and services was verified.

\section{Biotechnology as a springboard for sustainable development Sustainable development}

Industry 4.0 unites technology, things and human beings, promoting the automation of industrial (and/or business) processes in a broad way through the internet, artificial intelligence, robotics, among other mechanisms and technologies, which make possible to increase production (with great speed), reduce costs, errors and risks, save energy, increase the value of products, providing greater profitability to the entrepreneur and also greater satisfaction, and convenience to the customer. However, this socioeconomic development should be associated with environmental development. But what is meant by sustainability?

The concept of sustainability was born at the United Nations Conference on the Human Environment (Unche, June 1972), in Stockholm 


\section{S. Oreonnilda, A.C. Massabni}

(Sweden). In 1987, the UN World Commission on Environment and Development (UNCED) produced the Brundtland report (named "Our Common Future"), which practically reaffirmed the definition of sustainable development of the 1972 Conference: "Sustainable development is development that meets the needs of the present without compromising the ability of future generations to meet their own needs". In 1992, the United Nations Conference on Environment and Development (UNCED), held in Rio de Janeiro, also known as Rio92, Eco-92 or Earth Summit, demonstrated the world's interest in the future of the Earth; the participating countries reached consensus on the concept of sustainable development and began to shape actions with the aim of protecting the environment. ${ }^{16}$

Thus, sustainability is formed by a set of ideas, strategies and other attitudes ecologically correct, economically viable, socially fair and culturally diverse; it is the path to ensure the sustenance of the planet's natural resources, while at the same time allowing solution for ecological development of individuals and societies. ${ }^{17}$ In Rio-92, it was concluded that the economic, environmental and social components must be aggregated, without which there is no way to achieve, or rather, ensure the sustainability of development ${ }^{16}$.

It was evident that the definition of sustainability presupposes three pillars (economic, social and environmental), where economic sustainability refers to finance and involves financial resources, planning, organization and management of production, distribution and consumption of goods and services; aspect inherent to the country's economy, with variables in interest rates, credit lines for financing, GDP numbers, competitiveness in the international market, among other aspects relevant to the growth and development of the nation. ${ }^{11}$

Social sustainability, on the other hand, reveals aspects related to the human being and the community where it operates: labor force (labor force to companies), social inequality, education and violence, for example. A sustainable society presupposes that citizens have the minimum for a dignified life ${ }^{11}$. In short, social sustainability presupposes the eradication of poverty by promoting conditions of human equality and dignity for access to goods within an acceptable minimum limit.

Souza and Oliveira draw attention to the delicate and worrying issue of natural resources being finite assets and excessive exploitation causing extremely harmful results to society, most of the time these results are irreparable and irreversible. For this reason, the model of production and consumption should be compatible with the material basis of the economy. Every business activity entails impacts on the environment, with no exception, some more and some less. ${ }^{11}$

Environmental sustainability deals with the environment, natural resources, fauna and flora and their use; relevant factors that require care in the short, medium and long term. According to Elimar Pinheiro do Nascimento, sustainability in a simple way would be to produce and consume in a way that ensures that ecosystems can maintain their selfrepair or resilience capacity. ${ }^{18}$

Companies should adopt sustainable practices and be concerned about the effect that their activities cause to the environment and adopt actions to reduce these harmful impacts, because, as already stated, all activity promotes negative environmental impacts, but at this time Biotechnology joins as a strong ally to sustainable development.

\section{Biotechnology and sustainable development: technology for environmental protection}

The pioneering in the capture, processing, understanding and use of large amounts of data puts Biotechnology in a privileged position, no doubt the convergence of innovations will be intensified with the use of the power of digitalization and the practices of Industry 4.0 in the industrial biotechnology sector ${ }^{19}$. An example of Industry 4.0 is digital fermentation, which has been tested and applied in the textile sector.

In this sense, Biotechnology will provide essential innovations to protect the environment, such as the sustainable consumption of diesel, the reduction of the impact of waste in agroindustry, the alteration of energy sources by other more sustainable in the pharmaceutical industry, food and cosmetics, are some examples. What would be the impact of human action on the environment? What legacy will the current generation leave behind? As can be seen, sustainable development presupposes actions in the medium and long term in the economic, social and environmental areas.

Malajovich, citing reports published in 2007 by the Intergovernmental Panel on Climate Change (IPCC), demonstrates humanity's responsibility for the future of the planet, where it has been proven, more than a decade ago, that actions to protect the environment are urgent. ${ }^{2}$

Biotechnology startups work on the decontamination of polluted water, developing products and techniques without the need for river and lagoon drainage. Biopolymers and paraffin plates embedded with bacteria-activated nano-minerals have been shown to be very efficient and cheaper). ${ }^{20}$

Modern biotechnology marked the beginning of a new phase of agriculture, highlighting molecular genetics. Advances in plant genetics reduced the excessive dependence of agriculture on mechanical and chemical innovations, which were the pillars of the green revolution". It is worth noting the increase in productivity, the reduction of production costs, the production of better-quality food and the development of less harmful practices to the environment. ${ }^{21}$

The use of environmental biotechnologies are ways to minimize and even try to reverse the action of human degradation and the consequent production of waste, residues and pollutants by the exercise of the most diverse economic activities from the development of controlled natural processes aiming to reverse the pollution of ecosystems and create biodegradable solutions. As example, the reuse of sugarcane bagasse (agricultural waste) and sewage (solid effluents) for the production of biofuels and energy.

It is possible to buy products whose raw material was obtained from the use of biological materials (bacteria, yeasts, fungi, among others), such as fabrics manufactured by cultivating living organisms that produce a type of (bacterial) cellulose. ${ }^{22}$

Scientists reproduced synthetic spider silk in the laboratory. The material is flexible, lightweight, biodegradable and more resistant than steel. It can be used by the automotive, pharmaceutical and safety industries. Silk threads woven by spiders are 30 times thinner than human hair and stronger than Kevlar, a synthetic fiber used in the manufacture of bulletproof vests. ${ }^{23}$

Biotechnology can also be applied in mining. Widely used for mining in Australia, South Africa and Canada, bioleaching is a technology that uses biotechnological routes for the recovery of metals present in oxidized and sulphide ores or for the pretreatment of ores. ${ }^{24}$ Biolixiviation is used in more than $20 \%$ of the world's copper mines. It is estimated that $30 \%$ of the total volume of copper mined in Chile goes through this biotechnology process, while in China, Eldorado Gold recovers from 93 to $94 \%$ of gold from the Guizhou plant. ${ }^{25}$

Sustainable development presupposes production without degradation of the environment, a culture that should cover all levels of the organization. Companies need to adopt strategic plans or production projects that preserve the environment and its surroundings, and the use of technologies is an important instrument in fulfilling this responsibility. Many companies have already adopted sustainable development projects with the implementation of techniques such as: use and consumption of alternative energy sources such as solar, wind and geothermal; recycling of reusable materials; rational consumption of water and food and reduction of the use of harmful chemicals in food production.

Another example is the company Adidas, applying the Industry 4.0 model associated with sustainability, the company inaugurated in 2018 the first fully automated and $100 \%$ robotized factory in the United States, a speed factory (fast plant). The company has only 150 employees who direct the machines in production; additive manufacturing (3D printing) is used. Adidas states that this speed factory can make shoes and put them on the market three times faster than traditional production models. ${ }^{26}$ 
Asia's production moved to the USA, where most of the sneakers and sports products commercialized are concentrated, optimizing time and money, without having to travel between oceans, in addition, the production unit closest to the distribution centers brought savings with logistic resources (mainly in distribution and stock). This is a company strategy, but in addition to the positive results obtained by the enterprise, it is also possible to verify other benefits, included in the concept of sustainability, since the action, in addition to minimizing environmental impacts in relation to pollution, by reducing labor costs by transferring activities from Asia, which does not provide protection to workers (allows child labor and in exhaustive conditions, for example), has reduced the incidence of child labor and in conditions similar to slavery. The German company intends to produce a total of 1 million shoes per year by 2020 in its two speed factories. In addition, they develop technologies that allow consumers to create their own custom footwear. ${ }^{26}$

As can be seen, it is possible to unite innovation, technology, profitability and social responsibility, i.e., development must be sustainable at the economic, social and environmental interfaces.

Table 4 shows a few biotechnological alternatives to replace industrial processes and also to replace agricultural inputs demonstrating the role of Biotechnology in promoting sustainable development, providing that companies contribute significantly to reducing harmful impacts on the environment, fulfilling its social responsibility2,27-30:

\begin{tabular}{|c|c|c|c|}
\hline Alternatives & Main information & Application & $\begin{array}{l}\text { Practical examples and results } \\
\text { obtained }\end{array}$ \\
\hline $\begin{array}{l}\text { Enzyme } \\
\text { Technology }\end{array}$ & $\begin{array}{l}\text { Enzymes are non-toxic and } \\
\text { biodegradable }\end{array}$ & $\begin{array}{l}\text { Food, feed, detergent, textile, pulp } \\
\text { and paper and leather industries. }\end{array}$ & $\begin{array}{l}\text { Tanneries: } 40 \% \text { reduction in sulphur } \\
\text { derivatives; improvement in leather } \\
\text { quality; reduction in energy } \\
\text { consumption. } \\
\text { Bioplastic packaging based on } \\
\text { polymers of bacterial or vegetable } \\
\text { origin: Compostable in a few months } \\
\text { (rapid degradation). }\end{array}$ \\
\hline Biolixiviation & $\begin{array}{l}\text { Use of bacteria, from } \\
\text { Biotechnology and green } \\
\text { chemistry, to extract metals. } \\
\text { The bacteria feed on the } \\
\text { sulfur present in the ore and } \\
\text { produce sulfuric acid, } \\
\text { responsible for separating } \\
\text { the materials in the solution. }\end{array}$ & $\begin{array}{l}\text { Mining industry for copper, silver } \\
\text { and gold extraction. }\end{array}$ & $\begin{array}{l}\text { During this process, the pile of ore, } \\
\text { usually packed in large tanks (chemical } \\
\text { reactors), coated with steel and with a } \\
\text { special blanket to prevent leaks and } \\
\text { soil contamination, receives } \\
\text { continuous irrigation (solution } \\
\text { containing the bacteria) that } \\
\text { solubilizes the metals. }\end{array}$ \\
\hline Biofertilizers & $\begin{array}{l}\text { They contain living } \\
\text { biological agents that } \\
\text { promote plant development. }\end{array}$ & $\begin{array}{l}\text { Agricultural sector: } \\
\text { agroindustry/agrobusiness. }\end{array}$ & $\begin{array}{l}\text { Rhizobium: Symbiotic bacteria found } \\
\text { in the roots of legumes that fix } \\
\text { atmospheric nitrogen; the industrial } \\
\text { production of Rhizobia replaces } \\
\text { chemical products derived from } \\
\text { petroleum. }\end{array}$ \\
\hline $\begin{array}{l}\text { Biological } \\
\text { agents for pest } \\
\text { control }\end{array}$ & $\begin{array}{l}\text { Use of entomopathogenic } \\
\text { bacteria, fungi and viruses }\end{array}$ & $\begin{array}{l}\text { Agricultural sector: } \\
\text { agroindustry/agrobusiness. }\end{array}$ & $\begin{array}{l}\text { Metarhizium anisopliae fungus: } \\
\text { combat the sugarcane leafhopper } \\
\text { (Mahanarva posticata). Bacteria } \\
\text { Bacillus thuringiensis var israelensis: } \\
\text { larvae of the Aedes aegyptimosquito } \\
\text { and of the rubber bands (Simulium } \\
\text { spp). }\end{array}$ \\
\hline $\begin{array}{l}\text { Biodegradation / } \\
\text { aerobic } \\
\text { biodigestion }\end{array}$ & $\begin{array}{l}\text { Degradation of waste by the } \\
\text { action of organic } \\
\text { substances. }\end{array}$ & $\begin{array}{l}\text { Transformation of organic waste } \\
\text { into a compost for fertilizer, } \\
\text { reforestation, soil filling and } \\
\text { combating erosion. }\end{array}$ & $\begin{array}{l}\text { The natural decomposition of waste in } \\
\text { sanitary landfills produces biogas, } \\
\text { released into the atmosphere } \\
\text { contributes to the greenhouse effect } \\
\text { and climate change. }\end{array}$ \\
\hline $\begin{array}{l}\text { Power } \\
\text { generation: } \\
\text { biofuels }\end{array}$ & $\begin{array}{l}\text { Fuels of natural or biological } \\
\text { origin - renewable energy } \\
\text { source obtained by burning } \\
\text { biomass or derivatives. }\end{array}$ & $\begin{array}{l}\text { In many sectors of the economy; } \\
\text { they can replace (totally or partially) } \\
\text { fuels derived from oil and natural } \\
\text { gas. }\end{array}$ & $\begin{array}{l}\text { Genetic improvements (more resistant } \\
\text { and more productive plants) and } \\
\text { developing new planting systems to } \\
\text { increase efficiency. Examples of } \\
\text { biofuels are: ethanol, biodiesel, biogas } \\
\text { and vegetable oil. Cellulosic ethanol is } \\
\text { produced from sugarcane biomass } \\
\text { (straw and bagasse). }\end{array}$ \\
\hline $\begin{array}{l}\text { Production of } \\
\text { biopolymers (or } \\
\text { bioplastics) }\end{array}$ & $\begin{array}{l}\text { They are biodegradable, } \\
\text { produced from renewable } \\
\text { resources. }\end{array}$ & $\begin{array}{l}\text { In countless sectors of the } \\
\text { economy, such as for the } \\
\text { manufacture of packaging and } \\
\text { disposable materials; preparation of } \\
\text { micro and nanocapsules (with the } \\
\text { purpose of controlled release of } \\
\text { drugs). }\end{array}$ & $\begin{array}{l}\text { Lactic polyacid bioplastic (PLA) - by } \\
\text { fermenting starchy vegetables, } \\
\text { bacteria produce lactic acid. The } \\
\text { products (PLA) are used in packaging } \\
\text { (food, cosmetics and plastic bags), } \\
\text { plates, pens, glasses, 3D printing } \\
\text { filaments, among others. The } \\
\text { estimated period for the degradation } \\
\text { of PLA goes from six months to two } \\
\text { years, being easily degraded by the } \\
\text { action of water. }\end{array}$ \\
\hline
\end{tabular}

Table 4 - Biotechnology alternatives: replacement of industrial processes and agricultural inputs. 


\section{S. Oreonnilda, A.C. Massabni}

Another point about the performance of Biotechnology in cultivars is transgenics. The cultivation of transgenics has been carried out by many countries for years. In 2001, genetically modified crops were planted on more than 52 million hectares of land around the world. This is approximately three times the total land cultivated in Germany. The cultivation of new varieties is undoubtedly not restricted to emerging and developing countries such as Argentina and China. Positive results have also been found in South Africa and Indonesia. ${ }^{31}$

The German Ministry of Consumer Protection, Food and Agriculture has estimated that 60 to $70 \%$ of all food in the country is affected by green Biotechnology. The European community supplies only $35 \%$ of its protein-rich food needs, for example, and must import the remaining $65 \%$ from the USA, Brazil, Argentina and other countries outside the European community. Large-scale international experiments with the cultivation of GM plants confirm that agricultural biotechnology is an innovative, effective method with several benefits such as abundant harvests, more resistant to external agents, promoting positive impacts and improvements on human quality of life and economic profitability to agribusiness. ${ }^{31}$

The genetically modified organism (GMO) is a living organism, which can colonize new environments. The new characteristics and activities acquired by the plant from the transgenesis may include quantitative or qualitative alteration in the production of molecules (RNA, proteins and metabolism), and may still remain active even after the destruction of the GMO. 32

In this sense, some direct environmental impacts of GMO are:

1. Interaction with living organisms with a possible selection of organisms resistant to transgenicity and other consequences originating from the exogenous compound in the soil;

2. Change in persistence in the agricultural environment or invasiveness of the crop in natural environments;

3. Gene flow by pollinators in weeds and invasive plants.

On the other hand, the indirect impacts of changes in the environment may be:

1. Reduction in pest, disease or invasive plant control due to the development of tolerance to herbicides;

2. Effect on wild biodiversity - mass planting of monocultures that cause the reduction of genetic biodiversity and rupture of ecological niches, alteration in trophic chains due to impact on non-target organisms, with shortening or substitution of trophic chains or emergence of secondary pests;

3. Effect on water and soil - alteration in the use of herbicides and in patterns of cultivation and land use. ${ }^{32}$

The concern with safe products obtained by the performance of Biotechnology is a constant. The biosafety assessment of potential risks and their probabilities of occurrence should be judicious, with the widest possible coverage and rigorously executed in several aspects involved in human health, environment (ecosystems, fauna and flora) and, mainly, taking into account the unforeseen and potential changes in the long term - which has been unknown to researchers and scientists, because it is difficult to predict all risks, all changes (intentional or not; beneficial or not) that a GMO can trigger in the future. This seems to be an arduous and very difficult task.

\section{Conclusions}

The concept of Biotechnology is still incipient, however, the definition provided by the UN has prevailed. Biotechnology has a multidisciplinary character, involving several disciplines and research in the areas of biology, chemistry, biochemistry, pharmacy, medicine, microbiology, information technology, robotics, law, among others, whose methods include procedures for modifying living organisms, from the simplest to the most complex such as genetic manipulation and nanotechnology.

The concept of sustainability was born at the United Nations Con- ference on the Human Environment in 1972, and its definition was reaffirmed with minor changes in other meetings and events held by the UN.

The exercise of the property right guaranteed by FC/88 (Art. 5, item XXII) is limited by the principle of social function, by which the owner must meet the legal requirements regarding the construction, rational and adequate use; respect for the determinations for the protection of the environment and the exploitation of labor (labor relations); the exercise of the right to use, enjoyment and disposal of the property is limited to collective interests, and must promote the well-being not only to its owner, but to society as well. The company, as an asset that generates property rights, must achieve this social function, under penalty of suffering penalties, from a simple notification for adequacy until the expropriation of the asset (Arts. 182, §4 and 184, CF).

Industry 4.0 is the fruit of the Fourth Industrial Revolution, whose basis is the digital revolution (internet, robotics, artificial intelligence, data storage and automatic learning). It is promoting surprising technological advances, such as genetic sequencing, nanotechnology, renewable energies and 3D printers. It will take a joint work between governments, companies and societies to face the consequences of the Fourth Industrial Revolution that breaks down all paradigms and barriers of distance and, until then, the "impossible". The industry needs to be reinvented and new professionals will be needed, with education to manipulate, execute, manage and create technologies.

Biotechnology can help in the sustainable development of the country, enabling more competitive, dynamic and technological companies, to stay "alive" in the market, in addition to constituting a relevant instrument at the disposal of Industry 4.0 in fulfilling its social responsibility.

Biotechnological studies and breeding provide many advantages and contribute to economic, social and environmental development, but also have drawbacks, which deserve further analysis and caution in application/use, such as GMOs - transgenics can alter the natural balance and compromise biodiversity. There are several uncertainties about the biosafety of these products, what the potential risks would be and their likelihood of occurrence to human and animal health, especially in the long term.

Biotechnology is an essential tool for minimizing the impacts on the environment, its achievements in research, development and technological innovation in the most diverse areas of its operation will be the springboard for sustainable development of the Fourth Industrial Revolution.

The defense of the environment is a duty of everybody, each of us with his own responsibility, and we should fight to guarantee this fundamental right, provided in the Federal Constitution, to present and future generations.

\section{Acknowledgements}

The authors thank Fundação Nacional de Desenvolvimento do Ensino Superior Particular (Funadesp, Fundação de Amparo à Pesquisa do Estado de São Paulo (Fapesp) Grant n. 2017/11570-3 for financial support and Coordenação de Aperfeiçoamento de Pessoal de Nível Superior - Brasil (CAPES) - Finance Code 001 for financial support.

\section{References}

1. United Nations. Convention on biological diversity [Internet]. 1992 [cited 2019 Ago. 20]. Available at: https://www.cbd.int/doc/legal/ cbd-en.pdf

2. Malajovich MA. Biotecnologia. Rio de Janeiro: BTeduc; 2016.

3. Muñoz E. Biotecnología y sociedade: Encuentros y desencuentros. Madrid: Cambridge University Press; 2001.

4. Salgado EG, Neves FO. Depósitos estaduais de patentes em ramos da biotecnologia: análise dos estudos em alertas tecnológicos. In: XXXI Encontro Nacional de Engenharia de Produção. Belo Horizonte: ENEGEP; 2011 [cited 2019 Ago. 20]. Available at: http://www.abep- 
ro.org.br/biblioteca/enegep2011_TN_STO_139_881_18511.pdf

5. Silva EJ. The Colours of biotechnology: Science, development and humankind. Electron J Biotechnol. 2004;7(3):1-2.

6. Grupo de Pesquisa em Bioenergia (GBio); Instituto de Energia e Ambiente Universidade de São Paulo (IEE USP). Conceituando biomassa [Internet]. [cited 2019 Out. 14]. Available at: http://gbio.webhostusp.sti.usp.br/?q=livro/conceituando-biomassa

7. Vidali M. Bioremediation: an overview. Pure Appl Chem. 2001;73(7):1163-72. https://doi.org/10.1351/pac200173071163

8. Teixeira AZ, Nascimento MMF, Trindade JLF, Rodrigues SÁ. Caracterização físico-química, bioconversão de resíduos agroindustriais e comparação entre métodos de inoculação. $R$ Bras Tecnol Agroindustr. 2011;5(1Suppl):450-7. https://doi.org/10.3895/S198136862011000100008S1

9. Vogel-Heuser B, Hess D. Guest Editorial Industry 4.0 - Prerequisites and Visions. IEEE T Autom Sci Eng. 2016;13(2)411-3. https://doi. org/10.1109/TASE.2016.2523639

10. Schwab K. A Quarta Revolução Industrial. São Paulo: Edipro; 2016.

11. Souza O, Oliveira LJ. Globalização e relações de consumo: servidão moderna e degradação ambiental. Rev Direito Ambient Soc. 2016;6(2):156-78.

12. Agência USP de Inovação (AUSPIN). Tecnologias inovadoras para as áreas de meio ambiente e sustentabilidade são apresentadas na Expocietec 2018 [Internet]. 2018 [cited 2019 Aug. 20]. Available at: http://www.inovacao.usp.br/tecnologias-inovadoras-para-areas-de-meio-ambiente-e-sustentabilidade-sao-apresentadas-na-expocietec-2018/

13. Shannon N. Eco friendly: ecology meets economy. A with Honors Projects [Internet]. 2017. [cited 2019 Ago. 20]. Available at: http:// spark.parkland.edu/ah/201

14. Brasil. Constituição (1988). Constituição da República Federativa do Brasil. Brasília: Senado Federal; 1988. [cited 2019 Ago. 20]. Available at: http://www.planalto.gov.br/ccivil_03/constituicao/constituicaocompilado.htm

15. Tavares AR. Direito de propriedade. In: Curso de Direito Constitucional. São Paulo: Saraiva; 2017.

16. Cavalcanti C. Meio ambiente, desenvolvimento sustentável e políticas públicas. São Paulo: Cortez; 1997.

17. Sánchez LE, Croal P. Environmental impact assessment, from Rio92 to Rio+20 and beyond. Ambient Soc. 2012;15(3):41-54. https:// doi.org/10.1590/S1414-753X2012000300004

18. Nascimento EP. Trajetória da sustentabilidade: do ambiental ao social, do social ao econômico. Estud Av. 2012;26(74):51-64. https:// doi.org/10.1590/S0103-40142012000100005

19. Ustundag A, Cevikcan E. Industry 4.0: Managing the digital transformation. Cham, Switzerland: Springer; 2018. https://doi. org/10.1007/978-3-319-57870-5

20. Vialli A. Startups criam soluções para despoluir rios e lagos. Associação Brasileira das Empresas Estaduais de Saneamento (Aesbe) [Internet]. 2019. [cited 2019 Out. 10]. Available at: https://aesbe. org.br/startups-criam-solucoes-para-despoluir-rios-e-lagos/

21. Silveira JMFJ, Borges IC, Buainain AM. Biotecnologia e agricultura da ciência e tecnologia aos impactos da inovação. São Paulo
Perspec. 2005:19(2)101-14. https://doi.org/10.1590/S010288392005000200009

22. Johnson DC, Neogi NA, inventors; CP Kelco US Inc, assignee. Nonwoven fabric-like product using a bacterial cellulose binder and method for its preparation. US patent 4919753A. 24 Apr. 1990.

23. Hinman MB, Jones JA, Lewis RV. Synthetic spider silk: a modular fiber. Trends Biotechnol. 2000;18(9):374-9. https://doi.org/10.1016/ S0167-7799(00)01481-5

24. Serviço Geológico do Brasil (CPRM). Serviço Geológico do Brasil, da Alemanha e CETEM se reúnem para discutir o Projeto BioCobalto [Internet]. 17 abr. 2019. [cited 2019 Nov. 20]. Available at: https://www.cprm.gov.br/publique/Noticias/Servico-Geologico-do-Brasil\%2C-da-Alemanha-e-CETEM-se-reunem-para-discutir-0-Projeto-BioCobalto-5605.html.

25. Oliveira DM, Sérvulo EFC, Sobral LGS, Peixoto GHC. Biolixiviação: utilização de micro-organismos na extração de metais. Série de Tecnologia Ambiental. Rio de Janeiro: CETEM/MCT; 2010. [cited 2019 Out. 10]. Available at: http://mineralis.cetem.gov.br/bitstream/ cetem/317/1/sta-53.pdf

26. Ivanov D, Dolgui A, Sokolov B. The impact of digital technology and Industry 4.0 on the ripple effect and supply chain risk analytics. Int J Prod Res. 2019;57(3):829-46. https://doi.org/10.1080/00207543 .2018 .1488086

27. Bastos VD. Biopolímeros e polímeros de matérias-primas renováveis alternativos aos petroquímicos. Revista do BNDE. 2007;14(28):201-34.

28. Vasconcelos Y. Mineração com microrganismos. Pesquisa FAPESP, Engenharia Metalúrgica [Internet]. 2013 [cited 2019 Out. 10]. Available at: https://revistapesquisa.fapesp.br/2013/12/18/mineracao-com-microrganismos/

29. Vasconcelos Y. Lavoura mais produtiva. Pesquisa FAPESP, Biotecnologia-Genética [Internet]. 2018 [cited 2019 Out. 14]. Available at: https://revistapesquisa.fapesp.br/2018/02/15/lavoura-mais-produtiva-2/

30. Schenberg ACG. Biotecnologia e desenvolvimento sustentável. Estud Av. 2010;24(70):7-17. https://doi.org/10.1590/S010340142010000300002

31. Vásquez SF. Possíveis impactos da biotecnologia no meio ambiente, especialmente na população humana. Rev Biociênc. 2008;14(1):69-75.

32. Capalbo DMF, Dusi AN, Pires CS, Paula DP, Arantes OMN, Melo IS. OGM e biossegurança ambiental. In: Costa MAF, Costa MFB (org) Biossegurança de OGM: uma visão integrada. Rio de Janeiro: Publit; 2009. 